\title{
Evaluasi Desain Antarmuka Pengguna pada Website Broadband Learning Center Menggunakan Metode Innovation Difussion Theory - Technology Acceptance Model (IDT - TAM)
}

\author{
Rizky Arya Febriawan ${ }^{1}$, Puspita Kartikasari ${ }^{2}$ \\ Program Studi Sistem Informasi, Universitas Dinamika \\ Email: ${ }^{1} 14410100012 @$ dinamika.ac.id, ${ }^{2}$ kartikapuspitasari21@gmail.com
}

\begin{abstract}
Abstrak: Broadband Learning Center (BLC) adalah sarana pembelajaran komputer dan internet gratis bagi warga surabaya berbasis web. Selama digunakannya website ini belum pernah dilakukan evaluasi melalui feedback dari pengguna, sebagai upaya untuk mengetahui dampak dari sistem yang ada pada website BLC dalam proses pembelajaran dibidang teknologi informasi dan komputer melalui respon yang diberikan oleh masyarakat. Solusi yang diberikan adalah dengan menganalisis dan mengevaluasi website berdasarkan feedback dari pengguna dengan metode Innovation Difussion Theory (IDT) - Technology Acceptance Model (TAM). Penelitian ini menggunakan sampel sebesar 100 responden dari pengguna aplikasi BLC. Berdasarkan hasil pengolahan dan analisis data dengan metode IDT-TAM diperoleh hasil bahwa variabel faktor yang berinteraksi berpengaruh terhadap kegunaan sistem informasi, variabel faktor yang berinteraksi dan variabel kondisi objektif berpengaruh terhadap kemudahan yang dirasakan, selanjutnya variabel kemudahan yang dirasakan berpengaruh terhadap penggunaan saat ini. Dari hasil análisis dan evaluasi data selanjutnya disusun sebuah rekomendasi berupa tahapan redesign pada tampilan antarmuka website BLC.
\end{abstract}

Kata Kunci: metode IDT-TAM, desain antarmuka, Broadband Learning Center

\begin{abstract}
The Broadband Learning Center (BLC) is a computer and internet learning facility that is provided free of charge to residents of Surabaya. During the use of this website, there has never been an evaluation through user feedback, in an effort to find out from the system on the BLC website in the learning process in the field of information technology and computers through responses provided by the community. The solution provided is to analyze and approve websites that receive feedback from users with the Innovation Difference Theory (IDT) method - Technology Acceptance Model (TAM). This study uses a sample of 100 respondents from BLC application users. Based on the results of data processing and analysis using the IDT-TAM method, the results of factor variables related to the usefulness of information systems are obtained, factor variables discussed and objective variables related to facilitating are obtained, then the independent variables are expected about current usage. From the results of the analysis and evaluation of the data, an assessment is then made which consists of a redesign of the existing website interface design.
\end{abstract}

Keywords: IDT-TAM, User Interface Design, Broadband Learning Center

\section{PENDAHULUAN}

Di era teknologi saat ini yang kian berkembang pesat sudah menjadi salah satu kebutuhan utama masyarakat, pemerintah memaksimalkan teknologi internet di Surabaya agar menciptakan masyarakat yang kaya ilmu pengetahuan teknologi dan informasi supaya dapat bersaing di era dunia digital dan modern.

Fasilitas online disediakan Dinkominfo Pemkot Surabaya, pada tahun 2018 tercatat telah tersedia di 42 titik, hal ini masih belum sepenuhnya dimanfaatkan oleh masyarakat Surabaya secara maksimal, sehingga masih 
terjadi kurang pemahaman teknologi di kalangan masyarakat kota Surabaya. Oleh karena itu, dibentuklah program pelatihan internet untuk masyarakat Surabaya yaitu Broadband Learning Center (BLC) yang merupakan program literasi internet berupa pembelajaran dan pelatihan TIK bagi warga Surabaya yang diberikan secara gratis dan bersertifikat.

Website BLC adalah sarana pembelajaran telematika bagi warga yang tersebar di seluruh wilayah Surabaya. Website BLC dibangun dalam rangka untuk mencerdaskan kehidupan bangsa dan mendorong pertumbuhan berbagai inovasi dalam sistem pendidikan teknologi dan informatika. Perubahan besar dalam lingkungan global mengharuskan kita untuk mengembangkan sistem pendidikan lebih terbuka, luwes, berkualitas dan dapat diakses oleh siapapun yang memerlukan tanpa harus memandang usia maupun pengalaman pendidikan. Website BLC memudahkan warga surabaya dalam mengakses perangkat TIK. Terdapat kelompok penempatan BLC yang dibagi menjadi beberapa bagian, yaitu untuk wilayah keluarahan, kecamatan dan rusun.

Selama digunakannya website ini belum pernah dilakukan evaluasi melalui feedback dari pengguna, sebagai upaya untuk mengetahui dampak dari sistem yang ada pada website BLC dalam proses pembelajaran dibidang teknologi informasi dan komputer melalui respon yang diberikan oleh masyarakat. Penelitian ini dilakukan sebagai upaya untuk mengetahui dampak dari sistem website BLC melalui respon dari masyarakat, data yang didapat diolah dan disimpulkan untuk tujuan dan kegunaan tertentu.

Solusi yang ditawarkan adalah dengan menganalisis dan mengevaluasi website berdasarkan feedback dari pengguna dengan metode Innovation Difussion Theory (IDT) Technology Acceptance Model (TAM). Hasil yang diharapkan adalah rekomendasi untuk mengembangkan website pada BLC.

\section{METODE}

Proses penelitian ini dilakukan untuk memahami keseluruhan data dan digambarkan melalui tahapan penelitian mulai dari tahap perencanaan hinga tahap pengembangan. Tahap penelitian dijelaskan pada gambar 1 sebagai berikut:
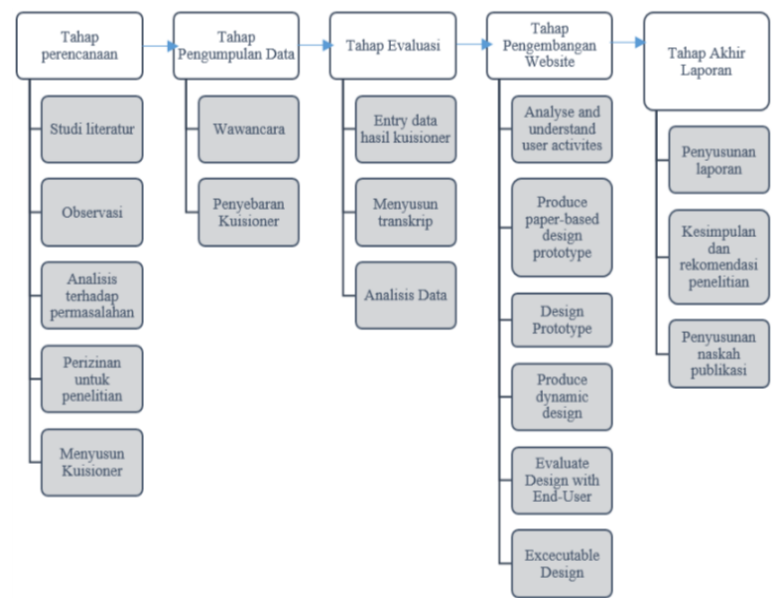

Gambar 1 Tahapan Penelitian

1. Tahap perencanaan terdiri dari studi literatur, observasi, analisis terhadap permasalahan, perizinan untuk penelitian, dan menyusun kuisioner.

2. Tahap pengumpulan data terdiri dari wawancara dan penyebaran kuisioner.

3. Tahap evaluasi terdiri dari entri data hasil kuisioner, menyusun transkrip, dan analisis data.

4. Tahap pengembangan website terdiri dari analyse and understand user activities, produce paper-based design prototype, design prototype, produce dynamic design, evaluate design with end-user, dan excecutable design.

5. Tahap akhir laporan terdiri dari penyusunan laporan, kesimpulan dan rekomendasi penelitian, dan penyusunan naskah publikasi.

\section{Tahap Perencanaan}

Observasi dilakukan dengan mengamati website saat ini mencakup semua hal yang ada dalam web BLC. Mulai dari halaman home, artikel, lokasi, testimoni, serta wilayah BLC.

Beberapa hasil observasi sebagai bahan rancangan pada tahap ini adalah

- Menu informasi singkat mengenai BLC, kekurangannya tidak adanya slide menyamping untuk menambah informasi singkat selanjutnya tentang BLC.

- Menu informasi artikel tentang BLC, mengenai berita terbaru apa saja yang terjadi pada BLC, namun kekurangannya adalah belum adanya update berita terbaru.

- Menu lokasi BLC yang menampilkan gambar lokasi BLC, kekurangannya adalah 
belum bisa menampilkan detil informasi pada lokasi BLC. Kekurangan lainnya belum ada informasi jam pelatihan, jumlah peserta saat ini, materi yang diajarkan, dan instruktur yang mengajar pada lokasi tersebut.

- menu testimoni ditampilkan dari penilaian masyarakat langsung yang sedang mengakses BLC. Kekurangannya adalah layar testimoni terlalu luas sehingga layar menjadi sempit dan terkuras.

- Menu informasi kontak, kekurangannya adalah informasi yang ditampilkan tidak lengkap dan media seperti halaman twitter dan facebook tidak ditampilkan untuk konsultasi kepada pengguna yang sedang mengakses web BLC. Kekurangan lainnya adalah informasi yang ditampilkan terlalu statis dan membosankan sehingga informasi ditampilkan ulang seperti pada halaman footer.

- Menu profil BLC, informasi yang ditampilkan tentang cara mendaftar, info pembelajaran, dan profil BLC, kekurangannya adalah menu yang di tampilkan masih sedikit, sehingga memakan ruang pada menu bar yang ada pada header.

- Menu pembelajaran tersedia jam untuk sesi pelatihan dan materi untuk pelatihan, kekurangan yang ada adalah belum ada pengelompokkan berdasar wilayah BLC sehingga pengguna yang mengakses kesulittan untuk mencari jadwal dan materi.

- Menu informasi visi, misi, moto, dan tujuan BLC. Kekurangan pada halaman profil BLC adalah informasi yang ditampilkan tertumpuk menjadi satu.

- Menu berita, kekurangannya pada halaman artikel tidak adanya informasi terbaru tentang berita BLC dan tanggal arsipnya tidak ada seperti menu untuk memilih tahun berita.

- Menu daftar nama instrukur yang ada pada BLC, kekurangannya adalah informasi yang ditampilkan hanya nama dan mengajar dimana, tidak adanya informasi tentang divisi pengajaran instruktur dan informasi kontak instruktur.

\section{Tahap Pengembangan Website}

- Pada tahap pengembangan website terdiri dari pembuatan skenario berjalannya website, mulai dari login, mendaftar, melihat informasi situs, dan melakukan entry data pada situs. Penyusunan alur website berfungsi sebagai gambaran kepada pengguna agar mudah dipahami website yang berjalan dimulai dari mana dan diakhiri bagaimana.

- Kegiatan desain dimulai dari satu set persyaratan yang sudah ditetapkan. Secara garis besar, ada dua jenis desain yaitu konseptual dan fisik. Desain konseptual berkaitan dengan pengembangan model konsep yang menangkap apa yang dilakukan dan bagaimana ia dilakukan, sementara desain fisik meliputi dengan detail desain seperti layar dan struktur menu, ikon, dan grafik. Desain muncul berulang kali melalui siklus evaluasi desain yang melibatkan bagaimana pengguna mengalaminya.

- Prototype adalah representasi terbatas dari desain yang memungkinkan pengguna untuk berinteraksi dan untuk menganalisis kesesuaiannya. Prototype adalah bantuan yang berguna ketika mendisuksikan ide dengan para pemangku kepentingan, mereka adalah alat komunikasi diantara anggota tip, dan merupakan cara yang efektif untuk menguji ide dari apa yang sudah dievaluasi.

Berikut adalah diagram alur dalam proses pembuatan sketsa yang dilakukan melalui hasil evaluasi dan prototype yang dijelaskan pada gambar 2 sebagai berikut:

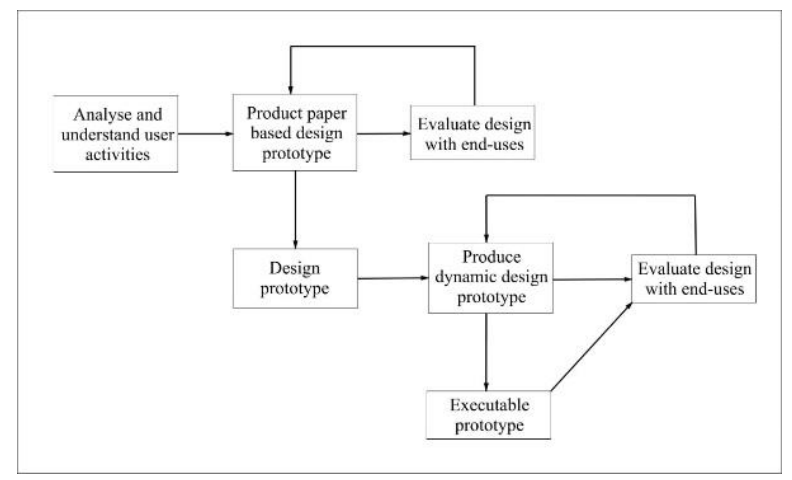

Gambar 2 Alur Perancangan Sketsa

(Sumber: Bernard, 2008)

Dalam alur perancangan skektsa website ada beberapa tahapan yang harus di selesaikan, tahapan berdasarkan sumber penelitian dari [1] tentang User Interface Design for e-Learning System yang dijelaskan sebagai berikut:

1. Analyse and understand user activites, mengetahui apa yang pengguna inginkan dari kegiatan yang terlibat dalam sistem. 
2. Produce paper-based design prototype, menggambarkan suatu peristiwa tentang website yang ada pada saat ini, kemudian di evaluasi kepada pengguna untuk mengetahui apa saja yang menjadi kekurangan pada website tersebut.

3. Design Prototype, berdasarkan hasil akhir dari sketsa langkah berikutnya adalah merancang dari sebuah sketsa kemudian menjadikannya sebuah gambar yang nyata, dengan melengkapi segala kekurangan yang ada pada website tersebut dengan menggunakan perangkat lunak Adobe XDesign dan MockingBot.

4. Produce dynamic design, mengetahui hasil evaluasi dari pengguna tentang kekurangan pada website, kemudian mulai

merancang website tersebut dengan memperhatikan kelemahan yang sudah dievaluasi dari pengguna secara dinamis, dan diberikan link pada masingmasing perintah pada desain website yang dirancang.

5. Evaluate Design with End-User, berdiskusi dengan pengguna yang memakai website dan membahas desain yang

sudah digambarkan dan dilengkapi dengan hasil evaluasi sebelumnya dari pengguna.

6. Excecutable Design, setelah hasil diskusic dengan pengguna, desain diterima dan dilakukan publikasi hasil proyek

\section{HASIL DAN PEMBAHASAN}

Hasil dan pembahasan meliputi pengujian statistik seperti reliabilitas, validitas, uji inner model, bootstraping, outer model, serta susunan prototipe desain website.

\section{Hasil Reliabilitas}

Dalam menghitung reliabilitas yang menggunakan Alpha Cronbach, maka uji reliabilitas [2] dilakukan secara bersama-sama terhadap seluruh butir pertanyaan jika Alpha Cronbach $<0.60$ sebagai berikut:

Tabel 1. Hasil Reliabilitas

\begin{tabular}{cc}
\hline \multicolumn{2}{c}{ Reliability Statistics } \\
\hline Cronbach's Alpha & N of Items \\
.899 & 22 \\
\hline
\end{tabular}

\section{Uji Validitas}

Setelah dilakukan penghitungan Alpha Cronbach secara keseluruhan, maka selanjutnya dilakukan penghitungan Uji Validitas atau R Tabel, dimana nilai $\mathrm{R}$ Tabel ditentukan oleh jumlah $\mathrm{N}$ atau jumlah populasi pada sampel. Populasi pada sampel sebesar 100 orang, maka $\mathrm{R}$ Tabel nya dihitung sebagai berikut:

$$
\begin{aligned}
\mathrm{R} \text { Tabel } & =\mathrm{R}(\alpha ; \mathrm{df}) \\
& =\mathrm{R}(0,05 ; \mathrm{N}-2) \\
& =\mathrm{R}(0,05 ; 100-2) \\
& =\mathrm{R}(0,05 ; 98)=0,1966
\end{aligned}
$$

\section{Outer Model}

Nilai Average Variance Extracted (AVE) harus memiliki nilai diatas 0,5 sebagai syarat mutlak bahwa variabel tersebut valid [3]. Syarat nilai AVE yaitu > 0,5 untuk menunjukkan ukuran nilai convergent validity atau validitas konvergen. Pada gambar 3 adalah model lengkap dari uji Average Variance Extracted (AVE) dari keseluruhan variabel pada metode IDT-TAM [4], dapat terlihat bahwa evaluasi subjektif, faktor yang berinteraksi, serta kondisi objektif memiliki nilai AVE dibawah 0,5, sedangkan kegunaan sistem informasi, kemudahan yang dirasakan, serta penggunaan saat ini sudah diatas nilai AVE 0,5 yang menunjukkan nilai convergent validity atau konvergensi validitas sudah baik.

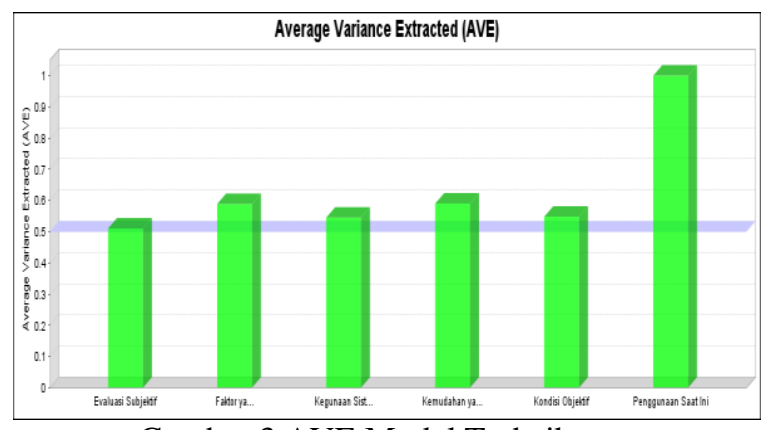

Gambar 3 AVE Model Terbaik

\section{Bootstraping}

Pengujian berikutnya adalah melakukan bootstraping untuk melakukan uji hipotesis yang akan dijelaskan pada gambaran untuk model struktural setelah dilakukannya bootsraping pada gambar 4 sebagai berikut: 


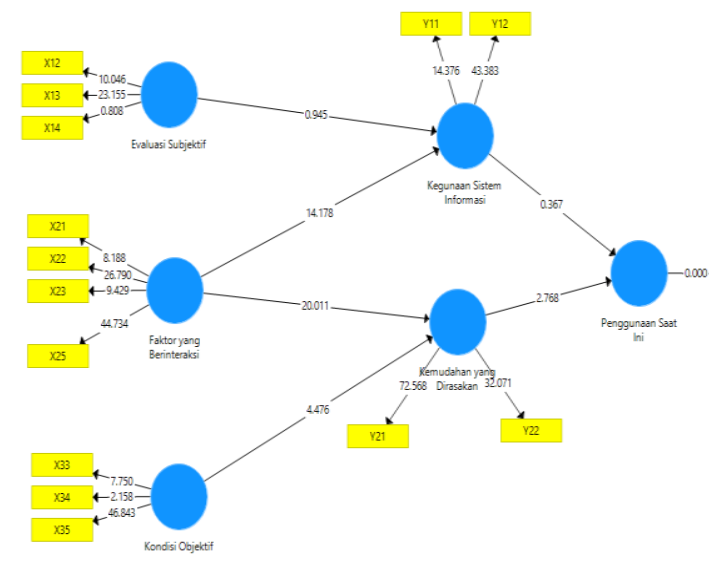

Gambar 4. Model Bootstraping

\section{Uji Hipotesis}

Berdasarkan hasil perhitungan bootstraping diatas, maka untuk melihat hubungan antar konstrukt variabel yang ditunjukkan oleh nilai $\mathrm{T}$ Statistic dengan membandingkan $\mathrm{T}$ Hitung dengan $\mathrm{T}$ Tabel, jika nilai $\mathrm{T}$ Hitung $>\mathrm{T}$ Tabel dengan nilai $(1,96)$ maka $\mathrm{H} 0$ diterima, namun jika nilai $\mathrm{T}$ Hitung $<\mathrm{T}$ Tabel $(1,96)$ maka H0 ditolak (Leli, 2014) yang ditunjukkan pada tabel 3 sebagai berikut:

Tabel 3. Uji Hipotesis

\begin{tabular}{|l|l|l|l|l|l|}
\hline \multicolumn{1}{|c|}{ Variabel } & $\begin{array}{c}\text { Original } \\
\text { Sample } \\
(\mathrm{O})\end{array}$ & $\begin{array}{c}\text { Sample } \\
\text { Mean } \\
(\mathrm{M})\end{array}$ & $\begin{array}{c}\text { Standard } \\
\text { Deviation } \\
(\text { STDEV) }\end{array}$ & $\begin{array}{c}\mathrm{T} \\
\text { Statistics }\end{array}$ & $\begin{array}{c}\mathrm{P} \\
\text { Values }\end{array}$ \\
\hline $\begin{array}{l}\text { Evaluasi Subjektif - } \\
\text { Kegunaan Sistem } \\
\text { Informasi }\end{array}$ & 0.066 & 0.072 & 0.070 & 0.945 & 0.345 \\
\hline $\begin{array}{l}\text { Faktor Yang Berinteraksi } \\
\text { > Kegunaan Sistem } \\
\text { Informasi }\end{array}$ & 0.794 & 0.795 & 0.056 & 14.178 & 0.000 \\
\hline $\begin{array}{l}\text { Faktor Yang Berinteraksi } \\
\text { - Kemudahan Yang } \\
\text { Dirasakan }\end{array}$ & 0.789 & 0.786 & 0.039 & 20.011 & 0.000 \\
\hline $\begin{array}{l}\text { Kegunaan Sistem } \\
\text { Informasi -> Penggunaan } \\
\text { Saat Ini }\end{array}$ & -0.071 & -0.034 & 0.194 & 0.367 & 0.713 \\
\hline $\begin{array}{l}\text { Kemudahan Yang } \\
\text { Dirasakan -> Penggunaan } \\
\text { Saat Ini }\end{array}$ & 0.590 & 0.553 & 0.213 & 2.768 & 0.006 \\
\hline $\begin{array}{l}\text { Kondisi Objektif -> } \\
\text { Kegunaan Sistem } \\
\text { Informasi }\end{array}$ & 0.211 & 0.214 & 0.047 & 4.476 & 0.000 \\
\hline
\end{tabular}

\section{Inner Model}

Setelah melakukan estimasi kriteria pada uji Outer Model dan Bootstraping, langkah analisis yang selanjutnya adalah melakukan pengujian Inner Model (Model Struktural) yang terdiri atas R2 dan F2 sebagai berikut:
Tabel 4. Tabel R Square

\begin{tabular}{lcc}
\hline & R Square & $\begin{array}{c}\text { R Square } \\
\text { Adjusted }\end{array}$ \\
\hline $\begin{array}{l}\text { Kegunaan sistem } \\
\begin{array}{l}\text { Informasi } \\
\text { Kemudahan Yang }\end{array}\end{array}$ & 0.689 & 0.683 \\
$\begin{array}{l}\text { Dirasakan } \\
\text { Penggunaan Saat Ini }\end{array}$ & 0.934 & 0.932 \\
\hline
\end{tabular}

\section{Hasil Evaluasi dan Rekomendasi}

Telah ditemukan bahwa dalam uji hipotesis variabel yang berpengaruh serta kecocokan antara saran responden adalah sebagai berikut:

1. Faktor yang Berinteraksi dengan Kegunaan Sistem Informasi

- Informasi terbaru setiap lokasi

- Penambahan fitur chat

- Sesi tanya jawab

- Waktu untuk diskusi tanya jawab

- Keluhan tempat sarana dan prasarana

- Foto peserta ketika latihan

2. Faktor yang Berinteraksi dengan Kemudahan yang dirasakan

- Daftar download modul

- Menambah materi yang bisa dicetak

- Warna website sering di update

3. Kondisi Objektif dengan Kemudahan yang dirasakan

- Instruktur ditempatkan sesuai lokasi

- Materi yang diajarkan ditempatkan sesuai tempat

4. Kemudahan yang dirasakan dengan penggunaan saat Ini

- Lebih sering untuk memperbarui website

- Isi website sering di update

- Peningkatan pada efektivitas website

Rekomendasi setelah dilakukannya kecocokan antara saran dan pengujian hipotesis adalah perancangan desain web BLC sesuai hasil evaluasi.

\section{Tahap Pengembangan Website}

Dalam pengembangan website langkah pertama adalah menyusun alur user-activites, untuk menjelaskan aktivitas user pengguna BLC. Analisis aktivitas user secara keseluruhan, dapat disimpulkan bahwa user memiliki aktiitas fungsional sebagai berikut: 
1. Halaman home

2. Halaman wilayah BLC

3. Halaman foto kegiatan

4. Halaman testimoni

5. Bar chat Customer Service

6. Bar chat sesama pengguna

7. Halaman download modul

8. Halaman instruktur

Analisis aktivitas admin secara keseluruhan, dapat disimpulkan bahwa admin memiliki aktivitas fungsional sebagai berikut:

1. Halaman dashboard

2. Halaman pengaturan chat Customer Service dan Pengguna

3. Halaman pengaturan menu bar about us dan informasi

4. Halaman pengaturan testimoni

5. Halaman pengaturan berita

6. Halaman pengaturan website BLC

\section{KESIMPULAN}

Berdasarkan hasil penelitian ini dapat disimpulkan sebagai berikut:

1. Ditemukan nilai dari uji reliabilitas sebesar 0,899 yang berarti data keseluruhan reliabel karena nilai $>0,60$.

2. Tersusun dengan desain user interface website BLC berupa front-end dan back-end sesuai dengan hasil hipotesis penelitian terhadap poin-poin penting dalam perancangan website.

3. Faktor-faktor yang berpengaruh adalah sebagai berikut:

- Evaluasi Subjektif berpengaruh terhadap variabel Penggunaan Saat Ini.

- $\quad$ Faktor yang Berinteraksi berpengaruh terhadap variabel Kemudahan yang Dirasakan dan Penggunaan Saat Ini.

- Kondisi Objektif berpengaruh terhadap variabel Penggunaan Saat Ini.

\section{DAFTAR PUSTAKA}

[1] Bernard, R. dan Agus, H. (2008). User Interface Design for e-Learning System. Yogyakarta: Universitas Gadjah Mada, Jurusan Teknik Informatika.

[2] Malhotra, N. B. (2007). Management Information Systems. Pearson.

[3] Tamara, Leli. (2014). Hubungan Persepsi, Kepuasan dan Loyalitas Pemustaka di
Perpustakaan Nasional Republik Indonesia. Institut Pertanian Bogor.

[4] Nan, Zhang. (2008). IDT-TAM Integrated Model for IT Adoption. China. 